\title{
Moult and autumn migration of non-breeding Fennoscandian Lesser White-fronted Geese Anser erythropus mapped by satellite telemetry
}

TOMAS AARVAK and INGAR JOSTEIN ØIEN

\begin{abstract}
Summary
In this study we demonstrate that non-breeding adult Lesser White-fronted Geese Anser erythropus from the Fennoscandian breeding population may undertake long-distance moult migration eastwards. Of three individuals equipped with satellite transmitters at a spring staging site in northern Norway, two migrated to moulting sites in the area of Kolgujev Island and Kanin Peninsula, while the third headed towards the Taimyr Peninsula, all in northern Russia. The first leg of the moult migration route for non-breeders was between Finnmark, Norway and the Kanin Peninsula area in north-western Russia, a similar route to that taken on autumn migration by Fennoscandian Lesser White-fronted Geese that had bred successfully. After the moulting period, one of the individuals followed a south-western route to Poland and Germany, where it spent the first part of the winter. The satellite signals from the other two geese ceased abruptly in early autumn, indicating that the birds may have been illegally shot in Russia. Locating new moulting and migration stopover sites is of crucial importance for the conservation of the critically endangered Fennoscandian subpopulation of this species.
\end{abstract}

\section{Introduction}

Lesser White-fronted Goose Anser erythropus is the most threatened Arctic goose species in the Palearctic region, and is listed as "Endangered" by Collar and Andrew (1988), as "globally threatened" (i.e. considered at risk of extinction if the negative trend continues) in Tucker and Heath (1994) and "Vulnerable" by BirdLife International (2000). The world population declined severely during the 1940 s and 1950 and has since continued to decrease. Recent estimates of the mid-winter population are no more than c. 25,000 individuals (Lorentsen et al. 1999, Tolvanen et al. 1999). In Fennoscandia there is a genetically distinct population (Ruokonen unpublished data) that is on the verge of extinction with 30 to 50 breeding pairs remaining out of an assumed population of 10,000 individuals at the beginning of the twentieth century (von Essen et al. 1996, Oien et al. 1996). Excessive hunting in the partly still unknown staging areas and wintering grounds is assumed to be the main reason for the population decline (Lorentsen et al. 1999). Lesser White-fronted Goose breeds in small numbers in scattered remote areas from northern Fennoscandia through wooded tundra in northern 
Siberia to Anadyr in north-eastern Russia, rendering large-scale ringing programmes and re-sightings of colour-marked birds impossible. Therefore, lightweight satellite transmitters (PTTs) have been used to unravel the species' autumn migration routes (Lorentsen et al. 1998, Øien et al. 1999).

A monitoring programme has operated at the Valdak Marshes in northern Norway since 1990 (cf. Øien et al. 1996, Aarvak and Øien 2000). This area is used by three-quarters of the known Fennoscandian population as the last staging area before the initiation of breeding and as the first post-moult staging area (Aarvak et al. 1999). The main aim of the monitoring is to assess population size and breeding success. Depending upon the number of successful breeding pairs, 30-95\% of the Lesser White-fronted Geese (adults and second-calendar-year birds) present during spring return to the same staging ground in autumn (Aarvak and Øien 1999).

A former satellite telemetry study of Lesser White-fronted Geese in Fennoscandia (Lorentsen et al. 1998), where they were instrumented at this staging site in northern Norway, has shown that pairs breeding successfully return after moult commences to the same staging areas as are used pre-breeding. Here, they spend about two weeks before they migrate eastwards to the Kanin Peninsula, northwest Russia, in early September, from where the migration routes divide. One route is towards the south-west, to staging areas north of the Onega and Ladoga lakes in Russia, in the former East Germany, Hungary and Northern Greece before eventually terminating in the wintering area at the Evros Delta on the border area of Greece and Turkey (Lorentsen et al. 1998). The other migration route is south-eastwards from the Kanin Peninsula passing the Ural Mountains to stage in the middle of the Ob River Valley (Lorentsen et al. 1998), and further south in northern Kazakstan (Karvonen and Markkola 1997). The principal wintering areas are unknown, but are possibly located on the southern shores of the Caspian Sea, e.g. in Turkmenistan, Azerbaijan and Iran (Lorentsen et al. 1999, Øien et al. 1999). Lesser White-fronted Geese tagged with satellite-transmitters at the Yamal and Taimyr peninsulas in northern Russia have shown that individuals from these breeding areas also migrate along the Ob River Valley southwards to northern Kazakstan (Karvonen and Markkola 1997, Øien et al. 1999). However, the high mortality rate due to high hunting pressure means that no individuals have been tracked all the way to the principal wintering areas. In 1996, an international action plan for the species was prepared by BirdLife International and published by the council of Europe (Madsen 1996). In this action plan, identification of key sites along the migration routes and during winter was determined to be the most essential action.

In this paper we report the results of satellite tracking of non-breeding Lesser White-fronted Geese in the period from pre-breeding through autumn migration. It is of vital importance to know where non-breeders are located during summer and early autumn in order to understand the spatial and temporal differences in the use of staging and wintering areas between different age and social classes of this population. This has consequences for population structuring (Ruokonen unpublished data) through, amongst others, timing of pair formation, pair-bond stability, assortative mating and encounter rate between individuals from different populations. Such knowledge is important for implementation of proper management regimes for this globally threatened species throughout its flyway. 


\section{Methods}

Six Lesser White-fronted Geese were caught at the Valdak Marshes $\left(70^{\circ} 09^{\prime} \mathrm{N}\right.$, $24^{\circ} 54^{\prime} \mathrm{E}$ ), in northern Norway in May 1997 (Table 1) by cannon netting. Øien et al. (1996) give a more thorough description of the catching area. Four of the geese were equipped with Microwave Nano platform terminal transmitters (PTT 100 series) weighing $35 \mathrm{~g}$ (40 g including harnesses) representing a mean of $2.1 \%$ of their body mass at the time of attachment (Table 1 ).

The satellite transmitters were attached as a backpack to the geese using $8 \mathrm{~mm}$ tubular Teflon tape harnesses. Two silver rings were attached to the harness, one behind and one in front of the sternum to avoid interference with the bird's wing and leg muscles. By continuous transmitting the batteries last for $c .500$ hours (P. Howey, Microwave Telemetry Inc., pers. comm.). Transmission was optimized for the migration of breeding birds in order to make the batteries last one year. With a varying duty cycle, they were programmed to send signals regularly (for eight hours every 3.3 days) during the presumed migration period, and less regularly during the breeding and wintering periods (every 20.3 days and 10.3 days respectively). When the geese were at stopover sites, local ornithologists were contacted in order to verify their presence by visual observations. All transmitters were equipped with English and Russian text-labels with contact addresses to increase the likelihood of obtaining additional information if the birds should be found dead.

Data on the positions of the birds were obtained via the ARGOS system. References to the accuracy of the location classes (LC) are those provided by ARGOS: class $3,<150 \mathrm{~m}( \pm 1 \mathrm{SD})$; class $2,150-350 \mathrm{~m}( \pm 1 \mathrm{SD})$; class $1,350-1,000 \mathrm{~m}$; class $\mathrm{O},>1,000 \mathrm{~m}$ (no estimate of accuracy); and class A and B, no estimate of location accuracy provided but has to be judged by the user (ARGOS 1996). Keating et al. (1991) suggested that with these standard deviations, $68 \%$ of the locations with values of 3,2 or 1 would be $\leqslant 226,528$ and $1,510 \mathrm{~m}$ respectively from the transmitters true position. Since most locations were of class o or poorer, the accuracy was assessed by comparing satellite locations of class $\mathrm{O}, \mathrm{A}$ and $\mathrm{B}$ with the similar locations where the exact position of the geese was known by visual observation.

Unlikely satellite positions were deleted manually. These were of location classes $\mathrm{O}, \mathrm{A}$ and $\mathrm{B}$, and they either indicated an improbable high flight speed $(>110 \mathrm{~km} / \mathrm{h})$ or errors in calculating accurate positions. Mirror image locations

Table 1. IDs and weight of satellite transmitters, biometric data and catching details for Lesser Whitefronted Geese caught in 1997 at the Valdak Marshes, Norway. Age is given in calendar years. Satellite transmitter weight includes harness and silver rings.

\begin{tabular}{|c|c|c|c|c|}
\hline \multirow{2}{*}{$\frac{\text { Data }}{\text { Ring number }}$} & \multicolumn{4}{|c|}{ Individuals } \\
\hline & 376979 & 376980 & 376982 & 376984 \\
\hline Satellite transmitter no. & 24676 & 25931 & 25930 & 24675 \\
\hline Satellite transmitter weight (g) & 40.0 & 40.0 & 40.0 & 39.0 \\
\hline Sex & M & M & M & M \\
\hline Age & $3^{+}$ & 2 & $3^{+}$ & $3^{+}$ \\
\hline Weight (g) & 2000 & 2030 & 1740 & 1870 \\
\hline Catching date & 25.05 & 27.05 & 27.05 & 27.05 \\
\hline Pair no. & A & single & B & $\mathrm{C}$ \\
\hline
\end{tabular}


were accepted, however, if they appeared probable compared with the former and latter positions (ARGOS, 1996).

The distances were measured as Great Circles (orthodromes) in ArcView 3.1 (cf. Gudmundsson and Alerstam 1998 on map projections for migratory research). The tracks are generated visually by an extension for ArcView 3.1 made by Hooge and Eichenlaub (1997).

\section{Results}

Plot location accuracy

A total of 245 locations were received during the lifetime of the four satellite transmitters. One of the transmitters (PTT 25931) failed to send any signals after this bird was released. Thirty-five of the locations (14.3\%) were considered unlikely and deleted after manual inspection. In another seven unlikely locations (2.9\%), the mirror images were accepted. Most of the approved locations (48.1\%) were of class $\mathrm{O}$, while $42.8 \%$ were of class A and B. Only $6.2 \%$ were of class 1,2 or 3 (Table 2 ).

A few locations were obtained when visual observations confirmed accurate positions. A total of 11 positions were obtained from two of the geese when they were still present at the Valdak Marshes after catching. The mean distance between the satellite locations and the true position of the geese was $5.8 \mathrm{~km}$ for $\mathrm{LC} \mathrm{o}(n=5, \mathrm{SD}=3.4), 12.8 \mathrm{~km}$ for LC A $(n=2, \mathrm{SD}=11.2)$ and $13.8 \mathrm{~km}$ for LC B $(n=4, \mathrm{SD}=2.4)$.

\section{Migration of individual geese}

Three of the four tagged geese started the moult and autumn migration with functioning transmitters. None of these individuals raised young to fledging that year, but it is unknown whether they attempted to breed or not.

The male with PTT 24675 arrived at the Valdak Marshes on 26 May. It was caught together with a female (pair C) on 27 May (Table 1) and was located in a breeding area in the central highlands of Finnmark County, northern Norway the day after, and stayed there at least until 26 June. Between 26 June and 6 July it moved to the Kanin Peninsula in north-west Russia. Here it stayed around the centre of the peninsula near the settlement of Kiya and eastwards (centre of locations $67^{\circ} 32^{\prime} \mathrm{N} 44^{\circ} 37^{\prime} \mathrm{E}$ ). Between 4 and 21 August, this individual migrated further south-eastwards, following the same route as two of the four satellite-

Table 2. Number and quality of locations received, and number of functioning days, for each of the satellite transmitters used on Lesser White-fronted Geese in this study. The accuracy of the location classes is described in the text.

\begin{tabular}{|c|c|c|c|c|c|c|c|c|c|}
\hline \multirow[t]{2}{*}{ Transmitter ID } & \multicolumn{6}{|c|}{ Location class distribution in \% } & \multirow[t]{2}{*}{ Total } & \multirow{2}{*}{$\begin{array}{l}\text { Mean no. per } \\
8 \text { h cycle }\end{array}$} & \multirow{2}{*}{$\begin{array}{l}\text { Lifetime } \\
\text { in days }\end{array}$} \\
\hline & B & A & o & 1 & 2 & 3 & & & \\
\hline 24675 & 23.1 & 23.1 & 50.0 & 3.8 & o & o & 26 & 2.9 & 88 \\
\hline 24676 & 20.0 & 17.1 & 60.0 & 2.9 & o & o & 35 & $4 \cdot 4$ & 73 \\
\hline 25930 & 25.5 & 22.1 & 45.0 & 4.7 & 0.7 & 2.0 & 149 & 4.2 & 219 \\
\hline 25931 & & & & & & & o & & o \\
\hline Total & $24 \cdot 3$ & 21.4 & 48.1 & $4 \cdot 3$ & 0.5 & 1.4 & & & \\
\hline
\end{tabular}


tagged birds in 1995, heading towards the Ural Mountains (see Lorentsen et al. 1998). We received the last location on 22 August, $30 \mathrm{~km}$ north-west of the settlement of Sen'kina $\left(66^{\circ} \mathrm{O}^{\prime} \mathrm{N} 50^{\circ} 11^{\prime} \mathrm{E}\right)$ in north-west Russia.

The male equipped with PTT 24676 arrived at the Valdak Marshes on 24 May, and was caught the following day (Table 1). This individual was paired (pair A), but the female was not caught. They stayed at the Valdak Marshes until 31 May. On 5 June the male was observed at the catching site alone, and on 7 June it was located in the same breeding area as PTT 24675. It migrated from the breeding area in Finnmark between 27 June and 7 July, and staged on the western part of the Kanin Peninsula in the outlet of the Torna River on 7 July $\left(68^{\circ} \mathrm{Oo}{ }^{\prime} \mathrm{N} 44^{\circ} 18^{\prime} \mathrm{E}\right)$. This area is known as an important staging area for Fennoscandian Lesser Whitefronted Geese in early autumn, and this site probably hosts the majority of the Fennoscandian Lesser White-fronted Goose population for a period of 2-3 weeks (Lorentsen et al. 1998, Tolvanen 1997). The next bout of signals revealed that this bird had migrated further and was, surprisingly, located $55 \mathrm{~km}$ east of the Pyasina River in the Yangoda area on the Taimyr Peninsula $\left(72^{\circ} 45^{\prime} \mathrm{N} 93^{\circ} \mathrm{O} 6^{\prime} \mathrm{E}\right)$ on 16 July. It stayed at this location until 5 August, when the last signal was received. This area was also used by another individual late in the breeding season in 1998, after being tagged with a satellite transmitter in the forest tundra of the Taimyr Peninsula (Øien et al. 1999).

The male with PTT 25930 arrived at the Valdak Marshes on 22 May, and was caught together with a female on 27 May (Table 1). This pair (B) was not subsequently seen together. The female was re-sighted at the catching site on 30 May, while the male was observed there on 29 May, 4 and 5 June. This male was also tracked to the same breeding area as the other two individuals. On 18 July it was located in the southern part of the Kolgujev Island in north-west Russia $\left(68^{\circ} 47^{\prime} \mathrm{N} 49^{\circ} \mathrm{O} 5^{\prime} \mathrm{E}-68^{\circ} 50^{\prime} \mathrm{N} 49^{\circ} 17^{\prime} \mathrm{E}\right.$ ) (Figure 1), where it staged until 21 August. On 25 August it was located on the coast of the Malozemelskaya Tundra in the area around Sen'yahka and Veikhniy Shar (centre: $68^{\circ} 22^{\prime} \mathrm{N} 51^{\circ} \mathrm{O} 7^{\prime} \mathrm{E}$ ) where it stayed until 26 September (Figure 1). It was then located to the north of the village of Vizhas on the south-east coast of the Kanin Peninsula $\left(66^{\circ} 49^{\prime} \mathrm{N} 45^{\circ} 49^{\prime} \mathrm{E}\right)$ on 30 September (Figure 1). The next signals, received 3 October, revealed another movement to the area between the Onega and Ladoga lakes $\left(61^{\circ} 28^{\prime} \mathrm{N} 33^{\circ} 52^{\prime} \mathrm{E}\right)$ north of St Petersburg, Russia (Figure 1). As was the case at the former location, it had another short stopover (less than six days) to the north-west of Warsaw in Poland around 7 October, and a short stopover south of Zmigrod $\left(51^{\circ} 22^{\prime} \mathrm{N} 18^{\circ}{ }^{\circ} 3^{\prime} \mathrm{E}\right)$. From this location it moved to the wetland areas around the Zmigrod and Milicz fish ponds, north of the city of Wroclaw $\left(51^{\circ} 31^{\prime} \mathrm{N} 16^{\circ} 55^{\prime} \mathrm{E}\right)$ where it stayed until 12 October before moving (short distances) within Poland, firstly south on 15 to 29 October $\left(50^{\circ} 54^{\prime} \mathrm{N} 16^{\circ} 18^{\prime} \mathrm{E}\right)$, then northwards again on 10 December $\left(51^{\circ} 32^{\prime} \mathrm{N} 16^{\circ} 11^{\prime} \mathrm{E}\right)$, before flying to an area north-east of the city of Halle in Germany on 20 December $\left(51^{\circ} 35^{\prime} \mathrm{N} 11^{\circ} 38^{\prime} \mathrm{E}\right)$. The last signal was received from this area on 31 December (Figure 1 ).

\section{Migration timing}

All three individuals left the breeding areas between late June and early July, about $1 \frac{1}{2}-2$ months earlier than normal for successful breeders (Lorentsen $e t$ al. 


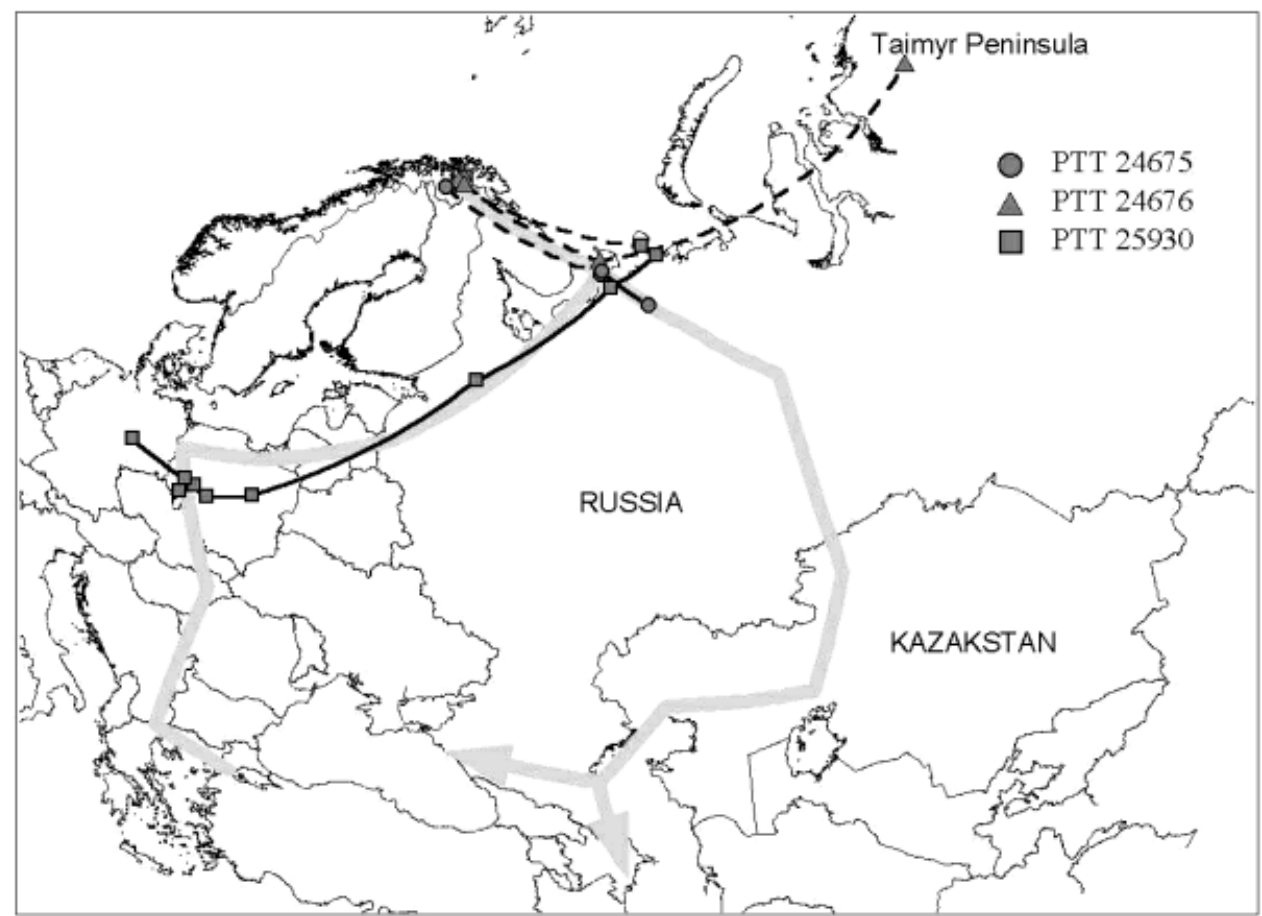

Figure 1. Complete tracks (Equidistant Azimutal projection) obtained from satellite transmitters (PTTs) attached to three Lesser White-fronted Geese, caught on the last staging post before breeding in Finnmark, Norway in 1997. Stippled lines show when migratory movements where earlier than for the breeding segment of the population. Grey bold lines show the autumn migration routes for successful breeders as described by Lorentsen et al. (1998) and Karvonen and Markkola (1997).

1998). They all staged for a period in north-west Russia (Kanin Peninsula and Kolgujev Island), which represents the site of migratory divide within the Fennoscandian population (Lorentsen et al. 1998). The two individuals (PTT 24675 and PTT 25930) that remained in this area for moulting started the main part of the autumn migration in middle/late August. This coincides with the period when successful breeders return to the Valdak Marshes in Norway. The non-breeders left their moulting area before the successful breeders could have caught up with them, showing that they did not meet at the Kanin Peninsula or surrounding areas for further migration southwards.

\section{Migration routes and distances}

Two of the geese (PTT 24675 and PTT 25930) followed the same migratory routes as found by Lorentsen et al. (1998) for successful breeding Fennoscandian Lesser White-fronted Geese: one route turned south-west and one south-east after dividing at the Kanin Peninsula. The major migratory legs (for PTT 24675 and PTT 25930) were between 800 and $1,300 \mathrm{~km}$ long (Table 3). The exception was PTT 24676 where the migrated distance was $1,850 \mathrm{~km}$ between the Kanin Peninsula 
Table 3. Tracking distances (orthodromes) between the location for each of the functioning satellite transmitters used on Lesser White-fronted Geese in 1997.

\begin{tabular}{|c|c|c|c|}
\hline Transmitter ID & 24675 & 24676 & 25930 \\
\hline \multicolumn{4}{|l|}{ Distances in $\mathrm{km}$ between: } \\
\hline Breeding area, Norway - Kanin Peninsula, Russia & 900 & & \\
\hline Kanin Peninsula, Russia - Sen'kina, Russia & 300 & & \\
\hline Breeding area, Norway - Kanin Peninsula, Russia & & 790 & \\
\hline Kanin Peninsula, Russia - Taimyr Peninsula, Russia & & 1850 & \\
\hline Breeding area, Norway - Kolgujev, Russia & & & 980 \\
\hline Kolgujev, Russia - Malozemalskaya Tundra, Russia & & & 90 \\
\hline Malozemalskaya Tundra, Russia - Kanin Peninsula, Russia & & & 284 \\
\hline Kanin Peninsula, Russia - Onega/Ladoga lakes, Russia & & & 830 \\
\hline Onega/Ladoga lakes, Russia - Warsaw, Poland & & & 1280 \\
\hline Warsaw, Poland - Wroclaw, Poland & & & 220 \\
\hline Wroclaw, Poland - Germany & & & 320 \\
\hline
\end{tabular}

and Taimyr Peninsula. The time between the transmissions (20.3 days) in this case was, however, sufficiently long for the goose to have possibly staged on the way.

\section{Discussion}

\section{Reliability of methods}

The satellite-fixed locations were similar in quality to those reported in the first study of Lesser White-fronted Geese migration using satellite-transmitters (Lorentsen et al. 1998). Despite the generally low accuracy, they were sufficient to locate the moulting and staging areas. In general, this species utilizes wetland areas close to river outlets that are easy to locate during surveys. In addition, staging sites in steppe and farmland areas are relatively easy to locate since the geese are dependent on larger lakes for night-time roosting. Nearly half of all locations (48\%) were of class o with an estimated mean distance between the location and the true position of $6 \mathrm{~km}$. This is in accordance with other studies using lightweight satellite transmitters (eg. Blouin et al. 1999, Ristow et al. 2000).

\section{Effects of transmitters}

No behavioural studies were carried out, since the geese left the breeding/staging areas in northern Norway earlier than the successful breeders and were therefore not observed during the annual post-breeding monitoring. However, previous studies have not found any differences in time spent feeding or preening between tagged and untagged Lesser White-fronted Geese after they had been carrying the transmitters for two months (Lorentsen et al. 1998). Two of the four birds they studied were paired, producing four goslings, the average brood size produced that autumn (Lorentsen et al. 1998). In this study, none of the geese reached the wintering areas before the signals ceased. The fate of these birds is not known, but hunting could have caused the termination of the signals. Other studies have shown that c. 50\% (6 of 13) of satellite transmitter tagged Lesser White-fronted Geese were shot during the autumn migration in Russia and 
former Soviet Republics (authors' unpubl. data, Lorentsen et al. 1998). The fact that all transmitters stopped transmitting abruptly suggests either transmitter failure or that the geese were shot. Harness-mounted transmitters are believed to have decreased survival of Brent Goose Branta bernicla nigricans (Ward and Flint 1995), whilst in Greater Snow Geese Anser caerulescens atlantica, Blouin et al. (1999) found that either catching the birds or the transmitter itself may have affected the social behaviour, thus making them more vulnerable to hunting. Butler et al. (1998) (using Pennycuick's aerodynamic model from 1989, with body drag coefficients from 1996) found that a $33 \mathrm{~g}$ satellite transmitter on a Barnacle Goose would have increased the mechanical flight costs by around I W (or $5 \%$ ). They concluded that there was no reason to believe that the effect was excessive, although they could not exclude the possibility that the PTTs had some adverse effects.

None of the three adult geese equipped with functioning satellite transmitters bred successfully in the study year. This was not believed to be an effect of the transmitters, as 1997 was a poor breeding season and only eight of 26 adult pairs present at the Valdak Marshes during spring staging were successful in producing goslings (Aarvak and Øien 2000). However, the catching and/or mounting of satellite transmitters could have caused disruption to the pairs for two of the males (PTT 24676 and PTT 25930). The magnitude of repairing and duration of pair-bonds in Lesser White-fronted Geese is unfortunately unknown.

\section{Moult migration}

Salomonsen (1968) was among the first to raise the question about moult migration in general. He reviewed the known documented moult migrations among groups of Anatidae. For Lesser White-fronted Goose the only information given was based on the work by Ekman (1922), who wrote that moulting birds of the alpine zone of Scandinavia withdraw to the uppermost parts of the mountains, where they gather in large flocks. Whether this reflects a genuine moult migration is, however, dubious. Probably it refers to breeders with goslings and failed breeders (late in the breeding season) that have moved upwards from the breeding area. In surveys carried out in the moulting period for breeding Lesser Whitefronted Geese in the Fennoscandian mountains in the 1990s, we have recorded few moulting adults without goslings (authors' unpubl. data). In addition, a variable number of the adult pairs present during springtime at the Valdak Marshes have been absent during autumn staging (Aarvak and Øien 1999, 2000), suggesting that they had possibly left earlier. Ekman (1922) stated that no moult migration in Lesser White-fronted Geese had been recorded from Siberia. However, Syroechkovski Jr (1996) reviewed the available information from northern Russia, and found that regular aggregations of moulting non-breeders could be found at several places on the Taimyr Peninsula to the north of the breeding habitats in the forest tundra subzone (see also Aarvak et al. 1997). The most recent observation was a flock of 500 individuals in August 1989, of which about half were able to fly (Prokosch and Hötker 1995). Krechmar (1966, cited in Syroechkovski Jr 1996) observed movements of flocks to the north in the pre-moulting period (late June) in the Pyasina forest tundra. In the Bolshezemelskaya Tundra, European Russia, Morozov (2000) found that Lesser White-fronted Geese that 
did not breed in the tundra of the Bolshaya Rogovaya River left for moulting sites in early July, although this may have been a consequence of unfavourable weather conditions that year. In addition, in the Polar Ural, some of the geese left for moulting areas during mid-summer (Morozov 2000).

A northward moult migration of non-breeding Lesser White-fronted Geese has also been noted in the east Siberian population. The main moulting locations for non-breeders were found in the basin of the rivers Melkaya and Volchya, which drain into the Indigirka Delta in Yakutia (Syroechkovski Jr 2000).

Contrary to other findings on the movements of Lesser White-fronted Geese, our study has, for the first time, documented that non-breeders can undertake a long-distance eastward migration to moult.

\section{Migration routes and distances}

The tagged Lesser White-fronted Geese left the breeding areas in Finnmark and flew eastwards, following the same major routes as found in a study of Fennoscandian Lesser White-fronted Geese that had bred successfully in 1995 (Lorentsen et al. 1998). The lengths of the migratory legs (Table 3) were also similar to those found by Lorentsen et al. (1998), ranging from 90 to $1,850 \mathrm{~km}$. However, removing local movements (e.g. between Kolgujev and Malozemalskaya Tundra, Russia) and allowing only for distances without staging on the way (e.g. between Kanin Peninsula and Taimyr Peninsula, Russia) the range was between 830 and $1,280 \mathrm{~km}$.

\section{Migration of individual geese}

The stopover site at Kolgujev Island fits well with observations from the Kanin Peninsula of this species migrating in a north-east direction. Here, migrating Lesser White-fronted Geese have been observed in early June, but also in early July, and these observations have been interpreted as evidence for the existence of a breeding population at Novaya Zemlja (Vinogradov 1995). Those migrating in early July are most probably non-breeders, and the results from this study suggest that these individuals are on their way to the moulting site at Kolgujev Island.

The individual that migrated all the way from northern Norway to the Taimyr Peninsula (PTT 24676) probably does not represent a common phenomenon for migrating Lesser White-fronted Geese. Migratory flights (spring and autumn migration) are costly in terms of fuel consumption (Alerstam and Hedenström 1998) and represent stages in the life cycle with high mortality risks (e.g. Owen and Black 1991, Pfister et al. 1998). Travelling at least 1,800 km further seems unlikely to be optimal in terms of energy expenditure and mortality risk. An alternative explanation, although speculative, could be that this male was born at Taimyr and was paired in the preceding winter with a female of Fennoscandian origin. If the breeding attempt was terminated (e.g. because the female died), the male could have returned to the natal or previously used moulting area, with the presumed advantages of being in a familiar area, e.g. to increase survival or improve feeding efficiency (cf. Anderson et al. 1992). Female-biased breeding 
philopatry is common in waterfowl (Anderson et al. 1992), whereas males tend to show more philopatry to wintering grounds (Robertson and Cooke 1999).

\section{Timing of migration}

Until now, the migratory movements in non-breeding and unsuccessful breeding Lesser White-fronted Geese in Fennoscandia have been virtually unknown. Such individuals were assumed to migrate out of the breeding areas earlier than successful breeders and possibly utilized the Valdak Marshes as a staging area during mid-summer. None of the three Lesser White-fronted Geese equipped with functioning satellite transmitters bred successfully and they all left the breeding areas in late June/early July. Due to the long break between each transmission period, they could possibly have utilized the Valdak Marshes, but no information was received on this. The timing of migration in these non-breeding individuals coincided with the average hatching dates as estimated from the onset of egg-laying in early June. This is similar to the pattern described for Lesser Snow Geese Anser caerulescens caerulescens at La Pérouse Bay, Northern Manitoba, Canada (Cooke et al. 1995). The departure northwards usually takes place when the winds are from the south and often coincides with a moult migration of Canada Geese Branta canadensis heading to the Hudson Bay coast (Cooke et al. 1995). Follestad (1994) found that most Bean Geese Anser fabalis arrived in a traditional moulting area in central Norway in late June/early July. A similar situation has also been reported for Pink-footed Goose Anser brachyrhynchus where non-breeders undertake a moult migration from Iceland to Greenland in late June and early July (Christensen 1967).

\section{Unresolved questions and implications for conservation}

In contrast to the latitudinal migratory system (travelling north-south) of Lesser White-fronted Goose populations breeding from Bolshezemelskaya Tundra to Anadyr, the Fennoscandian population migrates eastwards during autumn to the Kanin Peninsula area before turning southwards. These movements probably reflect colonization history, with a wave of colonization proceeding from the east to the west in the Western Palearctic and where new populations maintain the traditional migration routes (cf. Ruokonen unpublished data). In geese, young learn their migratory paths by following their parents, becoming imprinted on the areas and routes. Von Essen (1996, 1999) exploited parental imprinting in Lesser White-fronted Geese through a reintroduction project where he used Barnacle Geese as foster parents. The objective was to change the migration route from central Asia and south-eastern Europe to western Europe in order to establish more safe wintering areas for the species. Through 15 years with introductions of approximately 350 individuals, a small population of $>60$ birds of at least 2 years old has become established in northern Sweden (von Essen $e t$ al. 2000). The reproduction rate in this semi-wild population has however proved low compared with the wild Fennoscandian population. Due to genetic problems within the captive breeding stock (e.g. Ruokonen 2001), none have been introduced to the semi-wild population since 1999. In terms of the conservation of the wild population, reintroduction of individuals with a questionable genetic 
background should be avoided. In the International Action Plan for Lesser White-fronted Goose (Madsen 1996), reintroduction was given a low priority as a conservation measure.

The Fennoscandian subpopulation of Lesser White-fronted Geese is genetically distinct from other populations (Ruokonen unpublished data), and we therefore recommend it is treated as such and given the status of "critically endangered".

It is of crucial importance to implement conservation actions at stopover sites on autumn and spring migration for this subpopulation, as well as at breeding and moulting sites (e.g. Madsen 1996). All sites holding part of this subpopulation at any time of year should have their importance recognized at international level. Breeding, staging and wintering sites holding more than $1 \%$ of the total population qualify as BirdLife International Important Bird Areas. Tolvanen et al. (1999) argued that the threshold value for Europe should be c. 20 birds and not the current 30-78 that implies an unrealistic autumn population of 3,0007,800 individuals. Since the Fennoscandian population at present numbers only 30-50 pairs breeding in the Nordic countries, all staging areas that are regularly used even by very few birds qualify as IBAs, and should be protected. Appropriate surveillance of numbers and distribution of the population is therefore necessary to unveil still unknown sites of importance for the subpopulation. This study has uncovered such previously unknown staging and moulting sites for part of this population, and many of these sites have no legal protection at present. Results from this and earlier satellite-tracking studies have pinpointed the urgent need to reduce hunting pressure at a number of sites along the migration route. This can only be successfully implemented through an intensive focus on the most "dangerous" sites by national nature management bodies in all countries possessing staging, wintering or breeding Lesser White-fronted Geese in cooperation with international bird and nature conservation bodies. Our finding that non-breeders migrate in mid-summer to moulting sites in northern Russia improves our understanding of population dynamics and ecology, which is needed to conserve the species effectively. It is, however, important to keep in mind that the results of this study are based on tracks from only a single year, and it is possible that migratory routes may change between years as a consequence of changes in environmental conditions. Therefore, further studies on the migratory patterns of this species are highly desirable.

\section{Acknowledgements}

Thanks are due to Torkjell Morset for assistance in the field, and to Stabbursnes Naturhus and Museum for logistic support. We are indebted to Svein-Håkon Lorentsen at the Norwegian Institute for Nature Research for various support. He also, together with Minna Ruokonen and Petteri Tolvanen, gave valuable comments on the manuscript. Thanks also to Gudmundur A. Gudmundsson and an anonymous referee for comments on an earlier draft. We also acknowledge the very helpful comments provided by James Robinson, Richard Hearn and Seb Buckton. We are also indebted to Paul Shimmings for improving the English. The survey has been financially supported by the Directorate for Nature Management in Norway (DN), Ministry of Environmental Affairs - The County Gov- 
ernor of Finnmark and Porsanger Municipality. Permission to catch Lesser White-fronted Geese in the Nature Reserve was kindly provided by The County Governor of Finnmark, and permission to equip the geese with satellite transmitters were given by DN and the National Controlling Committee for Laboratory Animals.

\section{References}

Aarvak, T. and Øien, I. J. (1999) Monitoring and catching of staging Lesser White-fronted Geese at the Valdak Marshes in 1998. In: P. Tolvanen, I. J. Øien and K. Ruokolainen, eds. Fennoscandian Lesser White-fronted Goose conservation project. Annual report 1998. WWF Finland Report 10 and Norwegian Ornithological Society, NOF Rapportserie Report no. 1-1999: 22-27.

Aarvak, T. and Øien, I. J. (2000) Monitoring of Lesser White-fronted Geese at the Valdak Marshes in 1999. In P. Tolvanen, I. J. Øien and K. Ruokolainen, eds. Fennoscandian Lesser White-fronted Goose conservation project. Annual report 1999. WWF Finland Report 12 and Norwegian Ornithological Society, NOF Rapportserie Report no. 1-2000: 24-27.

Aarvak, T., Øien, I. J., Tolvanen, P. and Markkola, J. (1999) Two pieces of the spring migration puzzle of the Fennoscandian Lesser White-fronted Goose population in place. In: P. Tolvanen, I. J. Øien and K. Ruokolainen, eds. Fennoscandian Lesser White-fronted Goose conservation project. Annual report 1998. WWF Finland Report 10 and Norwegian Ornithological Society, NOF Rapportserie Report no. 1-1999: 27-30.

Aarvak, T., Øien I. J., Syroechkovski Jr., E. E. and Kostadinova, I. (1997) The Lesser Whitefronted Goose monitoring programme. Annual report 1997. Norwegian Ornithological Society. NOF Rapportserie Report no.5-1997. 68.

Alerstam, T. and Hedenström, A. (1998) The development of bird migration theory. J. Avian Biol. 29: 343-369.

Anderson, M. G., Rhymer, J. M. and Rohwer, F. C. (1992) Philopatry, dispersal and the genetic structure of waterfowl populations. Pp. 365-395 in B. D. J. Batt, A. D. Afton, C. D. Ankney, D. H. Johnson, J. A. Kadlec and G. L. Krapu, eds. Breeding ecology and management of waterfowl. Minneapolis: University of Minnesota Press.

ARGOS (1996) User's manual. Toulouse: CLS ARGOS.

BirdLife International (2000) Threatened birds of the world. Barcelona and Cambridge, U.K.: Lynx Editions and BirdLife International.

Blouin, F., Giroux, J. F., Ferron, J., Gauthier, G. and Doucet, G. J. (1999) The use of satellite telemetry to track Greater Snow Geese. J. Field Orn. 70: 187-199.

Butler, P. J., Woakes, A. J. and Bishop, C. M. (1998) Behaviour and physiology of Svalbard Barnacle Geese Branta leucopsis during their autumn migration. J. Avian Biol. 29: 536545 .

Christensen, N. H. (1967) Moult migration of Pinkfooted Goose (Anser fabalis brachyrhynchus Baillon) from Iceland to Greenland. Dansk Orn. Foren. Tidsskr. 61: 56-66.

Collar, N. J. and Andrew, P. (1988) Birds to watch. The ICBP world checklist of threatened birds. Cambridge, U.K.: ICBP (Techn. publ. 8).

Cooke, F., Rockwell, R. F. and Lank, D. B. (1995) The Snow Geese of La Pérouse Bay. Natural selection in the wild. New York: Oxford University Press (Oxford Ornithological Series 4).

Ekman, S. (1922) Djurvärldens utbredningshistoria på skandinaviska halvön. Bonnier, Stockholm (in Swedish).

von Essen, L. (1996) Reintroduction of Lesser White-fronted Geese (Anser erythropus) in Swedish Lapland (1981-1991). Gibier Faune Sauvage, Game Wildl. 13: 1169-1180.

von Essen, L. (1999) The Swedish reintroduction project of Lesser White-fronted Geese. 
In P. Tolvanen, I. J. Øien and K. Ruokolainen, eds. Fennoscandian Lesser White-fronted Goose conservation project. Annual report 1998. WWF Finland Report 10 and Norwegian Ornithological Society, NOF Rapportserie Report no. 1-1999: 53-55.

von Essen, L., Markkola, J., Aarvak, T. and Øien, I. J. (1996) The Lesser White-fronted Goose in Fennoscandia: past and present distribution. Poster abstract. In M. Birkan, J. van Vessem, P. Havet, J. Madsen, B. Trolliet and and M. Moser, eds. Proceedings of the Anatidae 2000 Conference, Strasbourg, France, 5-9 Dec. 1994. Gibier faune Sauvage, Game Wildl. 13: 1313-1314.

von Essen, L., Bylin, A. and Fagerström, B. (2001) The Swedish project on re-establishment of the Lesser White-fronted Goose in Swedish Lapland - a summary for 1999. In P. Tolvanen, I. J. Øien and K. Ruokolanen eds. Fennoscandian Lesser White-fronted Goose conservation project. Annual Report 1999. WUF Finland Report 12 and Norwegian Ornithological Society, NOF Rapportserie Report no. 1-2000: 38-39.

Follestad, A. (1994) The importance of a moulting area for Bean Goose in Nord-Trøndelag, Norway. NINA oppdragsmelding 268: 1-31. (in Norwegian)

Gudmundsson, G. A. and Alerstam, T. (1998) Optimal map projections for analysing longdistance migration routes. J. Avian Biol. 29: 597-605.

Hooge, P. N. and Eichenlaub, B. (1997) Animal movement extension to ArcView. Ver. 1.1. Anchorage, AK: Alaska Biological Science Center, U.S. Geological Survey.

Karvonen, R. and Markkola, J. (1997) Satellite follow-up of the Yamal Lesser white-fronted Goose Sibyako (the mother). In P. Tolvanen, K. Ruokolainen, J. Markkola and R. Karvonen, eds. Finnish Lesser White-fronted Goose conservation project. Annual report 1997. WWF Finland Report No 9: 36-37.

Keating, K. A., Brewster, W. G. and Key, C. H. (1991) Satellite telemetry: performance of animal-tracking systems. J. Wildl. Manage. 55: 160-171.

Krechmar, A. V. (1966) Birds of Western Taymyr. Annals of the Zoological Institute, USSR Acad. Sci.: vol. 39, Biology of birds. Nauka Pub., Leningrad. Pp. 185-312 (in Russian).

Lorentsen, S.-H., Øien, I. J., Aarvak, T. (1998) Migration of Fennoscandian Lesser Whitefronted Goose Anser erythropus mapped by satellite telemetry. Biol. Conserv. 84: 47-52.

Lorentsen, S.-H., Øien, I.J., Aarvak, T., Markkola, J., von Essen, L., Farago, S., Morozov, V., Syroechkovsky Jr., E. and Tolvanen, P. (1999) Lesser White-fronted Goose Anser erythropus. Pp. 144-161 in: J. Madsen, G. Cracknell and A. D. Fox, eds. Goose populations of the Western Palearctic. A review of status and distribution. Wetlands International Publ. No. 48, Wetlands International, Wageningen, The Netherlands. National Environmental Research Institute, Rönde, Denmark.

Madsen, J. (1996) Lesser White-fronted Goose. In: Heredia, B., Rose, L. and Painter, M., eds. Globally threatened birds in Europe. Action Plans. Strasbourg. France: Council of Europe.

Morozov, V. V. (2000) Surveys for Lesser White-fronted Goose in the Bolshezemelskaya Tundra, European Russia, in 1999. In P. Tolvanen, I. J. Øien and K. Ruokolainen, eds. Fennoscandian Lesser White-fronted Goose conservation project. Annual report 1999. WWF Finland Report 12 and Norwegian Ornithological Society, NOF Rapportserie Report no. 1-2000: 35-38.

Øien, I. J., Aarvak, T., Lorentsen, S.-H. and Bangjord, G. (1996) Use of individual differences in belly patches in population monitoring of Lesser White-fronted Goose Anser erythropus at a staging ground. Fauna norv. Ser. C, Cinclus 19: 69-76.

Øien, I. J., Tolvanen, P., Aarvak, T., Litvin, K. and Markkola, J. (1999) Survey and catching of Lesser White-fronted Geese at Taimyr Peninsula 1998: preliminary results on autumn migration routes mapped by satellite telemetry. In: P. Tolvanen, I. J. Øien and K. Ruokolainen, eds. Fennoscandian Lesser White-fronted Goose conservation project. Annual report 1998. WWF Finland Report 10 and Norwegian Ornithological Society, NOF Rapportserie Report no. 1-1999: 37-41. 
Owen, M. and Black, J. M. (1991) The importance of migration mortality in non-passerine birds. Pp. 361-372 in: C. M. Perrins, J.D. Lebreton and G. J. M. Hirons, eds. Bird population studies. Relevance to conservation and management. Oxford: Oxford University Press, Oxford.

Pfister, C., Kasprzyk, M. J. and Harrington, B. A. (1998) Body-fat levels and annual return in migrating Semipalmated Sandpipers. Auk 115: 904-915.

Prokosch, P. and Hötker, H. (1995) Faunistik und Naturschutz auf Taimyr - Expeditionen 1989-1991. Corax 16, sonderheft. Sonderheft der Schriftenreihe Nationalpark Scleswigholsteinisches wattenmer.

Ristow, D., Berthold, P., Hashim, D. and Querner, U. (2000) Satellite tracking of Cory's Shearwater migration. Condor 102: 699-702.

Robertson, G. J. and Cooke, F. (1999) Winter philopatry in migratory waterfowl. Auk 116: 20-34.

Ruokonen, M. (2001) Phylogeography and conservation genetics of the Lesser Whitefronted Goose (Anser erythropus). Academic dissertation. Department of Biology, University of Oulu, Finland.

Salomonsen, F. (1968) The moult migration. Wildfowl 19: 5-24.

Syroechkovski Jr, E. E. (1996) Present status of the Lesser White-fronted Goose (Anser erythropus) populations in Taimyr and some peculiarities of the system of species migrations in the Western Palearctic. Bulletin of Goose Study Group of Eastern Europe and North Asia (Casarca) 2: 71-112 (in Russian with English summary).

Syroechkovski, Jr, E. E. (2000) New breeding and moulting areas of Lesser White-fronted Goose revealed in Indigirka, Yakutia. In P. Tolvanen, I. J. Øien and K. and Ruokolainen, eds. Fennoscandian Lesser White-fronted Goose conservation project. Annual report 1999. WWF Finland Report 12 and Norwegian Ornithological Society, NOF Rapportserie Report no. 1-2000: 39-40.

Tolvanen, P. (1997) Lesser White-fronted Goose Anser erythropus expedition to the Kanin Peninsula in 26 August - 12 September, 1996, and the establishment of the Shoininsky Reserve. In P. Tolvanen, K. Ruokolainen, J. Markkola and R. Karvonen, R., eds. Finnish Lesser White-fronted Goose conservation project. Annual report 1997. WWF Finland Report 9: 33-35.

Tolvanen, P., Markkola, J., Aarvak, T., Øien, I. J. (1999) Introduction. In P. Tolvanen, I. J. Øien and K. Ruokolainen, K.,eds. Fennoscandian Lesser White-fronted Goose conservation project. Annual report 1998. - WWF Finland Report 10 and Norwegian Ornithological Society, NOF Rapportserie Report no. 1-1999: 5-8.

Tucker, G. M. and Heath, M. F. (1994) Birds in Europe: their conservation status. Cambridge, U.K.: Birdlife International (Birdlife Conservation Series no.3).

Vinogradov, V. G. (1995) Lesser White-fronted Goose on Novaya Zemlya and the Kanin peninsula. IWRB, Threatened Waterfowl Research Group Newsletter No.8, October: 11-12

Ward, D. H. and Flint, P. L. (1995) Effects of harness-attached transmitters on premigration and reproduction of brant. J. Wildl. Manage. 59: 39-46.

TOMAS AARVAK and INGAR JOSTEIN ØIEN

Norwegian Ornithological Society, Sandgata 30B, N-7012 Trondheim, Norway.

Received 22 March 2002; revision accepted 30 January 2003 